\title{
Implementasi Nilai-nilai Moral dan Agama pada Anak Usia Dini
}

\author{
Rizki Ananda ${ }^{凶}$ \\ Dosen Program Studi Pendidikan Guru Sekolah Dasar \\ Universitas Pahlawan Tuanku Tambusai
}

\begin{abstract}
Abstrak
Salah satu sikap dasar yang harus dimiliki seorang anak untuk menjadi seorang manusia yang baik dan benar adalah memiliki sikap dan moral dan keagamaan yang baik dalam berperilaku sebagai umat Tuhan, anggota keluarga, dan anggota masyarakat. Usia Anak Usia Dini adalah saat yang paling baik bagi guru Pendidikan Anak Usia Dini (PAUD) untuk meletakkan dasardasar pendidikan moral dan keagamaan kepada terhadap. Walaupun peran orang tua sangat besar dalam membangun dasar moral dan agama bagi anak-anaknya, tetapi peran guru PAUD juga tidak kecil dalam meletakkan dasar moral dan keagamaan bagi seorang anak, karena biasanya anak usian dini cenderung menuruti perintah gurunya. Oleh karena itu seorang guru PAUD harus selalu berupaya dengan berbagai cara agar dapat membimbing anak usia dini agar mempunyai kepribadian yang baik, yang dilandasai dengan nilai moral dan agama. Dengan diberikannya landasan pendidikan moral dan agama kepada anak PAUD, maka seorang anak PAUD dapat belajar membedakan perilaku yang baik dan buruk, benar dan salah, serta terbiasa menjalankan ajaran agama sesuai dengan tingkat pertumbuhan dan perkembangannya. Mendidik anak PAUD dengan pendidikan moral dan agama yang baik, bukanlah pekerjaan yang mudah dilakukan, oleh karena itu guru PAUD harus selalu meningkatkan wawasan, pemahaman dan keterampilan terkait pengembangan moral dan agama anak PAUD.
\end{abstract}

Kata kunci: nilai-nilai moral, nilai agama, anak usia dini

\begin{abstract}
One of the basic attitudes a child must have to be a good and righteous man is to have good moral and religious attitudes and behaviors in behaving like God's people, family members, and community members. Early Childhood Age is the best time for teachers of Early Childhood Education (PAUD) to lay the foundations of moral and religious education to the. Although the role of parents is enormous in establishing the moral and religious foundations of their children, the role of the early childhood teacher is not small in laying down the moral and religious grounds for a child, since usually, the early child tends to follow his teacher's instructions. Therefore, an early childhood teacher should always try in various ways in order to guide early childhood to have a good personality, which is based on moral and religious values. With the foundation of moral and religious education to children of early childhood, an early childhood can learn to distinguish good and bad behavior, right and wrong, and accustomed to run the teachings of religion in accordance with the level of growth and development. Educating PAUD children with good moral and religious education is not an easy task, therefore PAUD teachers should always improve their insight, understanding, and skills related to the development of morals and religion of children in early childhood.
\end{abstract}

Keywords: moral values, religious values, early childhood

@ Jurnal Obsesi Prodi PG-PAUD FIP UPTT 2017

$\triangle$ Corresponding author :

Address: Perum Attaya Ridan Permai Bangkinang Kab. Kampar

ISSN 2356-1327 (Media Cetak)

Email : rizkiananda.mhs.upi@gmail.com ISSN 2549-8959 (Media Online) 


\section{PENDAHULUAN}

Anak adalah penerus generasi keluarga dan bangsa. Sebagai generasi penerus, setiap anak perlu mendapat pendidikan yang baik sehingga potensipotensi dirinya dapat berkembang dengan pesat, tumbuh menjadi manusia yang memiliki kepribadian tangguh dan memiliki berbagai macam kemampuan serta keterampilan yang bermanfaat. Oleh karena itu penting bagi orang tua dan lembaga-lembaga pendidikan berperan serta bertanggung jawab dalam memberikan berbagai macam stimulasi dan bimbingan yang tepat sehingga akan tercapai generasi penerus yang tangguh.

Dalam Undang-Undang Sistem Pendidikan Nasional (SISDIKNAS) Nomor 20 Tahun 2003 disebutkan pendidikan bertujuan "mengembangkan kemampuan dan membentuk watak serta peradaban bangsa yang bermartabat dalam rangka mencerdaskan kehidupan bangsa, bertujuan untuk berkembangnya potensi peserta didik agar menjadi manusia yang beriman dan bertakwa kepada Tuhan Yang Maha Esa, berakhlak mulia, sehat, berilmu, cakap, kreatif, mandiri, dan menjadi warga negara yang demokratis serta bertanggung jawab". (Republik Indonesia, 2003).

Sementara itu dalam Peraturan Menteri Pendidikan Nasional Nomor 16 Tahun 2007 kompetensi yang harus dimiliki guru adalah "menguasai karakteristik peserta didik pada aspek fisik, moral, sosial, kultural, emosional, dan intelektual". (Depdiknas, 2007)

Tuntutan kompetensi ini mengharuskan guru untuk mempelajari, memahami, dan mampu mengimplementasikan konsepsi perkembangan anak usia dini dan mengarahkannya pada aspek moral, sosial, kultural, emosional, dan intelektual yang lebih baik.

Oleh karena itu, kajian terhadap implementasi nilai moral dan agama bagi anak usia dini, khususnya anak usia 0-6 tahun menjadi sangat penting dan strategis bagi guru PAUD maupun pengelola PAUD secara keseluruhan. Mengingat fenomena negatif yang mengemuka dan sering menjadi tontonan dalam kehidupan seharihari. Melalui media cetak maupun elektronik dijumpai kasus-kasus anak usia dini sudah mulai meniru ujaran kebencian (hate speech), berbicara kurang sopan, senang meniru adegan kekerasan, bahkan meniru perilaku orang dewasa yang belum semestinya dilakukan anak-anak. Kondisi ini tentu cukup beralasan, mengingat pada fase ini anak usia 0-6 menurut para ahli berada pada fase peniruan (imitasi). Jadi, apapun kejadian-kejadian yang terjadi di sekitar lingkungan anak dengan sangat cepat diserap dan ditiru untuk dijadikan sebuah kebiasaan. Jika fenomenafenomena yang dilihat anak cenderung ke arah negatif maka kecenderungan perilaku menyimpang akan lebih mengemuka terjadi pada anak.

Kondisi ini tentu tidak seharusnya terjadi pada pendidikan anak usia dini, mengingat dunia anak seharusnya merupakan dunia yang penuh dengan kesenangan untuk pengembangan diri, yang sebagian besar waktunya semestinya diisi dengan belajar melalui berbagai jenis permainan di lingkungan sekitarnya.

Diperlukan penanaman nilai-nilai dan norma-norma Agama yang kuat terhadap bangsa ini agar tidak mudah terpengaruh dan mempunyai filter ketika pengaruhpengaruh bangsa lain masuk. Supaya penanaman nilai dan norma tersebut kuat, maka harus dilakukan sejak usia dini (Fauziddin, 2016).

Untuk itu, kajian tentang implementasi nilai moral dan agama terhadap anak usia dini ini akan menjadi landasan bagi upaya penanaman perilaku seperti yang tercantum dalam pengembangan tujuan pendidikan nasional. Selain itu pada kajian ini akan dipaparkan juga berbagai kompetensi yang diperlukan pendidik dalam upaya penanaman nilai moral dan agama dalam lembaga pendidikan anak usia dini lainnya. Hal ini dilandasi oleh pemikiran bahwa untuk dapat mengelola pembelajaran di PAUD, maka kemampuan guru dalam menginternalisasikan nilai moral dan agama bagi anak usia dini merupakan tuntutan yang tidak boleh diabaikan. 
Hal penting berikutnya yang tidak boleh dilupakan adalah fakta bahwa anak usia dini (0-6 tahun) sering disebut sebagai the golden age fase, karena pada masa ini berbagai kemampuan anak tumbuh dan berkembang dengan sangat pesat. Pemberian stimulasi dan fasilitas yang tepat pada masa ini akan sangat berpengaruh pada proses perkembangan anak selanjutnya dan sebaliknya apabila lingkungan sekitar seperti keluarga, sekolah, dan masyarakat tidak memberikan stimulasi yang tepat bagi pengembangan nilai-nilai moral dan agama maka perilaku amoral dan sikap bertentangan dengan norma agama yang akan cenderung muncul pada diri anak.

\section{PENGEMBANGAN NILAI MORAL}

\section{Teori Tentang Moral}

Pengertian moral, menurut Suseno dalam (Kurnia, 2015) adalah ukuran baikburuknya seseorang, baik sebagai pribadi maupun sebagai warga masyarakat, dan warga negara. Sedangkan pendidikan moral adalah pendidikan untuk menjadikan anak manusia bermoral dan manusiawi. Sedangkan menurut Ouska dan Whellan (Kurnia, 2015), moral adalah prinsip baikburuk yang ada dan melekat dalam diri individu/seseorang. Walaupun moral itu berada dalam diri individu, tetapi moral berada dalam suatu sistem yang berwujud aturan. Moral dan moralitas memiliki sedikit perbedaan, karena moral adalah prinsip baik-buruk sedangkan moralitas merupakan kualitas pertimbangan baikburuk. Dengan demikian, hakekat dan makna moralitas bisa dilihat dari cara individu yang memiliki moral dalam mematuhi maupun menjalankan aturan.

Ada beberapa pakar yang mengembangkan pembelajaran nilai moral, dengan tujuan membentuk watak atau karakteristik anak. Pakar-pakar tersebut diantaranya adalah Newman, Simon, Howe, dan (Lickona, 1992). Dari beberapa pakar tersebut, pendapat (Lickona, 1992) yang lebih cocok diterapkan untuk membentuk watak/ karater anak. Pandangan (Lickona, 1992) tersebut dikenal dengan educating for character atau pendidikan karakter/watak untuk membangun karakter atau watak anak. Dalam hal ini, Lickona mengacu pada pemikiran filosofi Michael Novak yang berpendapat bahwa watak/ karakter seseorang dibentuk melalui tiga aspek yaitu, moral knowing, moral feeling, dan moral behavior, yang satu sama lain saling berhubungan dan terkait. Lickona menggarisbawahi pemikiran Novak. Ia berpendapat bahwa pembentukan karakter/watak anak dapat dilakukan melalui tiga kerangka pikir, yaitu konsep moral (moral knowing), sikap moral (moral feeling), dan prilaku moral (moral behavior). Dengan demikian, hasil pembentukan sikap karekter anak pun dapat dilihat dari tiga aspek, yaitu konsep moral, sikap moral, dan perilaku moral.

Pemikiran Lickona ini mengupayakan dapat digunakan untuk membentuk watak anak, agar dapat memiliki karakter yang baik. Oleh karena itu, materi tersebut harus menyentuh tiga aspek teori (Lickona, 1992), seperti berikut. Konsep moral (moral knowing) mencakup kesadaran moral (moral awarness), pengetahuan nilai moral (knowing moral value), pandangan ke depan (perspective talking), penalaran moral (reasoning), pengambilan keputusan (decision making), dan pengetahuan diri (self knowledge). Sikap moral (moral feeling) mencakup kata hati (conscience), rasa percaya diri (self esteem), empati (emphaty), cinta kebaikan (loving the good), pengendalian diri (self control), dan kerendahan hati (and huminity). Prilaku moral (moral behavior) mencakup kemampuan (compalance), kemauan (will) dan kebiasaan (habbit).

Berdasarkan uraian di muka, dapat disimpulkan bahwa pengertian moral/ moralitas adalah suatu tuntutan prilaku yang baik yang dimiliki individu sebagai moralitas, yang tercermin dalam pemikiran/konsep, sikap, dan tingkah laku. Dan pengembangan moral ini sangat penting untuk dilakukan pada anak di Taman Kanak-Kanak. 


\section{Pola Orientasi Moral Anak Taman Kanak-Kanak}

Pada usia Taman Kanak-kanak anak telah memiliki pola moral yang harus dilihat dan dipelajari dalam rangka pengembangan moralitasnya. Orientasi moral diidentifikasikan dengan moral position atau ketetapan hati, yaitu sesuatu yang dimiliki seseorang terhadap suatu nilai moral yang didasari oleh cognitive motivation aspects dan affective motivation aspects.

Menurut (Dewey, 1997) tahapan perkembangan moral seseorang akan melewati 3 (tiga) fase, yaitu premoral, conventional dan autonomous. Anak Taman Kanak-kanak secara teori berada pada fase pertama dan kedua. Oleh sebab itu, guru diharapkan memperhatikan kedua karakteristik tahapan perkembangan moral tersebut. Sedangkan menurut Piaget, seorang manusia dalam perkembangan moralnya melalui tahapan heteronomous dan autonomous.

Seorang guru PAUD harus memperhatikan tahapan hetero-nomous karena pada tahapan ini anak masih sangat labil, mudah terbawa arus, dan mudah terpengaruh. Mereka sangat membutuhkan bimbingan, proses latihan, serta pembiasaan yang terus-menerus. Moralitas anak Taman Kanak-kanak dan perkembangannya dalam tatanan kehidupan dunia mereka dapat dilihat dari sikap dan cara berhubungan dengan orang lain (sosialisasi), cara berpakaian dan berpenampilan, serta sikap dan kebiasaan makan. Demikian pula, sikap dan perilaku anak dapat memperlancar hubungannya dengan orang lain.

Pengembangan moral kepada anak usia Taman Kanak-kanak dapat dilakukan dengan berbagai cara dan lebih disarankan untuk menggunakan pendekatan yang bersifat individual, persuasif, demokratis, keteladanan, informal, dan agamis. Beberapa program yang dapat diterapkan di Taman Kanak-kanak dalam rangka menanamkan dan mengembangkan perilaku moral anak di antaranya dengan bercerita, bermain peran, bernyanyi, mengucapkan sajak, dan program pembiasaan lainnya.

Perkembangan moral dan etika pada diri anak Taman Kanak-kanak dapat diarahkan pada pengenalan kehidupan pribadi anak dalam kaitannya dengan orang lain. Misalnya, mengenalkan dan menghargai perbedaan di lingkungan tempat anak hidup, mengenalkan peran gender dengan orang lain, serta mengembangkan kesadaran anak akan hak dan tanggung jawabnya. Puncak yang diharapkan dari tujuan pengembangan moral anak Taman Kanak-kanak adalah adanya keterampilan afektif anak itu sendiri, yaitu keterampilan utama untuk merespon orang lain dan pengalamanpengalaman barunya, serta memunculkan perbedaan-perbedaan dalam kehidupan teman disekitarnya. Hal yang bersifat substansial tentang pengembangan moral anak usia Taman Kanak-kanak di antaranya adalah pembentukan karakter, kepribadian, dan perkembangan sosialnya.

Guru Taman Kanak-kanak harus menguasai strategi pengembangan emosional, sosial, moral dan agama bagi anak Taman Kanak-kanak. Juga, guru Taman Kanak-kanak perlu untuk senantiasa mengadakan penelitian tentang pengembangan dan inovasi dalam bidang pendidikan bagi anak usia prasekolah.

\section{Tahap Perkembangan Moral Anak Usia Dini}

Ruang lingkup tahapan/pola perkembangan moral anak di antaranya adalah tahapan kejiwaan manusia dalam mengpengembangankan nilai moral kepada dirinya sendiri, mempersonalisasikan dan mengembangkannya dalam pembentukan pribadi yang mempunyai prinsip, serta dalam mematuhi, menentukan pilihan, menyikapi, atau melakukan tindakan nilai moral Menurut Piaget anak berpikir tentang moralitas dalam 2 cara, yaitu cara heteronomous (usia 4-7 tahun ), di mana anak menganggap keadilan dan aturan sebagai sifat-sifat dunia (lingkungan) yang tidak berubah dan lepas dari kendali manusia dan cara autonomous (usia 10 
tahun keatas) di mana anak sudah menyadari bahwa aturan-aturan dan hukum itu diciptakan oleh manusia.

Menurut (Kohlberg, 1995), perkembangan moral anak usia prasekolah berada pada tingkatan yang paling dasar, yaitu penalaran moral prakonvensional. Pada tingkatan ini anak belum menunjukkan pengembangan nilai-nilai moral. Pertimbangan moralnya didasarkan pada akibat-akibat yang bersifat fisik dan hedonistik. Ada 4 (empat) area perkembangan yang perlu ditingkatkan dalam kegiatan pengembangan atau pendidikan usia prasekolah, yaitu perkembangan fisik, sosial emosional, kognitif dan bahasa.

\section{Esensi, Prinsip-prinsip, dan Bentuk Kegiatan Pengembangan Moral Anak Usia Dini}

\section{a. Esensi Pengembangan Moral AUD}

Pengembangan nilai moral dalam program pendidikan TK dimasukkan dalam bidang pembentukan perilaku merupakan kegiatan yang dilakukan secara terus menerus dan ada dalam kehidupan sehari-hari anak di TK, sehingga aspekaspek perkembangan tersebut diharapkan berkembang secara optimal. Tujuan yang hendak dicapai dengan pengembangan nilai moral tersebut dilakukan melalui pembiasaan dalam rangka mempersiapkan anak sedini mungkin mengembangkan sikap dan perilaku yang didasari oleh nilai moral sehingga dapat hidup sesuai dengan norma-norma yang dianut oleh masyarakat.

Pengembangan nilai moral ini berfungsi untuk mencapai beberapa hal:

1) Agar perilaku dan sikap anak didasari oleh nilai moral sehingga anak dapat hidup sesuai dengan nilai-nilai yang dijunjung oleh masyarakat

2) Membantu anak agar tumbuh menjadi pribadi yang matang dan mandiri

3) Melatih anak untuk dapat membedakan sikap dan perilaku yang baik dan yang tidak baik sehingga dengan sadar berusaha menghindarkan diri dari perbuatan tercela

\section{b. Prinsip-Prinsip Moral AUD}

Dalam melaksanakan program pembentukan perilaku melalui pembiasaan, hendaknya memperhatikan prinsip-prinsip sebagai berikut :

1) Guru menciptakan hubungan yang baik dan akrab sehingga tidak ada kesan bahwa guru adalah figur yang menakutkan bagi anak.

2) Guru senantiasa bersikap dan bertingkah laku yang dapat dijadikan contoh/teladan bagi anak

3) Memberikan kesempatan kepada anak untuk membedakan dan memilih mana perilaku yang baik dan mana yang tidak baik. Guru sebagai pembimbing hanya mengarahkan dan menjelaskan akibat-akibatnya.

4) Dalam memberikan tugas kepada anak agar diusahakan berupa ajakan dan perintah dengan bahasa yang baik

5) Agar anak mau berperilaku sesuai dengan yang diharapkan guru memberikan rangsangan (motivasi) dan bukan paksaan.

6) Apabila ada anak yang berperilaku berlebihan, hendaknya guru berusaha untuk mengendalikan tanpa emosi.

7) Terhadap anak yang menunjukkan perilaku bermasalah, peran guru adalah sebagai pembimbing dan bukan penghukum.

8) Pelaksanaan program pembentukan perilaku bersifat luwes/fleksibel.

\section{c. Bentuk Kegiatan dalam Pengembangan Nilai Moral}

Pelaksanaan kegiatan program pengembangan Moral dapat dilakukan dengan cara sebagai berikut :

\section{1) Kegiatan Rutin}

Kegiatan rutin yaitu kegiatan yang dilakukan setiap hari. Dalam kegiatan rutin guru dapat mengembangakan moral anak, seperti

a) Berbaris memasuki ruang kelas Sebelum memulai kegiatan belajar akan ditanamkan beberapa perilaku anak antara lain 1) Untuk selalu tertib dan patuh pada peraturan. 2) Tenggang rasa terhadap keadaan 
24 Implementasi Nilai-nilai Moral dan Agama pada Anak Usia Dini

orang lain. 3) Sabar menunggu giliran. 4) Mau menerima dan menyelesaikan tugas.

b) Mengucapkan salam

Pada waktu mengucapkan salam ditanamkan pembiasaan, antara lain 1) Sopan Santun, 2) Menunjukkan reaksi dan emosi yang wajar ,3) Sikap menghormati orang lain. 4) Menciptakan suasana keakraban.

c) Berdo'a sebelum dan sesudah kegiatan

Pada waktu berdo'a akan dikembangkan nilai moral, antara lain: 1) Memusatkan perhatian dalam jangka waktu tertentu. 2) Berlatih untuk selalu tertib dan patuh pada peraturan. Selain itu dapat juga diamati hal-hal sebagai berikut : 1) Bersikap tertib, dan tenang dalam berdo'a. 2) Keimanan dan ketaqwaan kepada Tuhan Yang Maha Esa 3) Mematuhi peraturan/tata tertib, dsb

d) Kegiatan belajar mengajar

Yang ingin ditanamkan pembiasaan perilaku pada waktu kegiatan belajar mengajar, antara lain 1) Tolong menolong sesama teman. 2) Rapi dalam bertindak - berpakaian dan bekerja. 3) Berlatih untuk selalu tertib dan patuh pada peraturan. 4) Berani dan mempunyai rasa ingin tahu yang besar. 5) Merasa puas atas prestasi yang dicapai dan ingin terus meningkatkan. 6) Bertanggung jawab terhadap tugas yang diberikan 7) Menjaga kebersihan lingkungan 8) Mengendalikan emosi. 9) Menjaga keamanan diri. 10) Sopan santun. 11) Tenggang rasa terhadap keadaan orang lain.

e) Waktu istirahat/makan/bermain

Pada waktu istirahat/makan/bermain dapat ditanamkan sikap moral, antara lain: 1) Tolong menolong sesama teman. 3) Tenggang rasa terhadap keadaan orang lain. 6) Sabar menunggu giliran. 8) Meminta tolong dengan baik. 9) Mengucapkan terima kasih dengan baik. 10) Membuang sampah pada tempatnya. 12) Menjaga keamanan diri

\section{2) Kegiatan Spontan}

Kegiatan spontan yaitu kegiatan yang dapat dilaksanakan secara spontan pada saat itu juga. Kegiatan ini biasanya dilakukan pada saat guru mengetahui sikap/tingkah laku anak yang kurang baik, seperti seorang anak menerima atau memberikan sesuatu kepada orang lain dengan tangan kiri, meminta sesuatu dengan berteriak, dsb. Apabila guru mengetahui sikap/perilaku anak yang demikian, hendaknya secara spontan diberikan pengertian dan diberitahu bagaimana sikap/perilaku yang baik. Misalnya kalau menerima atau memberikan sesuatu harus tangan kanan dan mengucapkan terima kasih.

Demikian juga kalau meminta sesuatu hendaknya dengan sopan dan tidak berteriak. Kegiatan spontan tidak saja berkaitan dengan perilaku anak yang negatif, tetapi pada sikap/ perilaku yang positif pun perlu ditanggapi oleh guru, sebagai penguat bahwa sikap/perilaku tersebut sudah baik dan perlu dipertahankan, sehingga dapat pula dijadikan teladan bagi teman temannya. Misalnya pada saat makan bersama ada seorang anak yang tidak membawa makanan, kemudian Amir memberi sebagian makanannya kepada teman tersebut. Sikap guru dalam hal ini adalah memberikan pujian kepada Amir dan mengatakan bahwa perbuatannya merupakan sikap yang terpuji karena telah memberi sebagian makanan kepada teman yang memerlukan.

\section{3) Kegiatan dengan "Teladan/Contoh"}

Kegiatan dengan teladan/contoh yaitu kegiatan yang dapat dilakukan dengan memberikan teladan / contoh kepada anak. Dalam hal ini guru berperan langsung sebagai teladan/ contoh bagi anak. Segala sikap dan tingkah laku guru, baik di sekolah, di rumah maupun di masyarakat hendaknya selalu menunjukkan sikap dan tingkah laku yang baik.

\section{4) Kegiatan yang Direncanakan (Terprogram)}

Kegiatan yang direncanakan (terprogram) yaitu kegiatan yang dalam pelaksanaanya terlebih dahulu diawali 
dengan adanya perencanaan atau program dari guru. Dan kegiatan tersebut harus terlihat jelas pada Rencana Pelaksanaan Pembelajaran Harian (RPPH) dan Rencana Pelaksanaan Pembelajaran Mingguan (RPPM).

\section{Ruang Lingkup Materi Pengembangan Moral di TK}

Ruang lingkup pengembangan moral dalam rangka pembentukan karakter menurut (Megawangi, 2010) adalah sebagai berikut :

a) Cinta Tuhan dan segenap ciptaanNya, b) tanggung jawab, Kedisiplinan dan Kemandirian, c) kejujuran, d) hormat dan santun, e) dermawan, suka menolong dan gotongroyong/kerjasama, f) percaya diri, kreatif dan pekerja keras, g) kepemimpinan dan keadilan, h) baik dan rendah hati, i) oleransi, kedamaian dan kesatuan, j) 4K ( kebersihan, kesehatan, kerapian dan keamanan)

Sementara pada pedoman pendidikan karakter bagi anak usia dini yang dikeluarkan oleh Direktorat Pembinaan Pendidikan Anak Usia Dini Direktorat jenderal pendidikan Anak Usia Dini, Nonformal, dan Informal terkait dengan karakter yang dikembangkan di Taman Kanak-kanak adalah:

a) kecintaan terhadap Tuhan YME, b) kejujuran, c) disiplin, d) toleransi dan cinta damai, e) percaya diri, f) mandiri, g) tolong menolong, kerjasama, dan gotong royong, $h$ ) hormat dan sopan santun, i) tanggung jawab, j) kerja keras, k) kepemimpinan dan keadilan, 1) kreatif, m) rendah hati, dan n) peduli lingkungan, o) cinta bangsa dan tanah air. (Kementrian Pendidikan Nasional, 2012)

\section{Metode dan Pendekatan, dalam Pengembangan Moral AUD}

a. Bentuk pelaksanaan kegiatan program pengembangan Moral dapat dilakukan dengan cara rutin, spontan, keteladanan, dan terprogram dengan metode: berceritera, bernyanyi, bersajak, karyawisata,

permainan tradisional, dan sebagainya.

b. pendekatan yang dapat digunakan dalam penanaman nilai moral pada anak usia dini di antaranya: indoktrinasi, klarifikasi nilai, teladan atau contoh, dan pembiasaan dalam perilaku.

\section{PENGEMBANGAN NILAI AGAMA}

\section{Pengertian Agama}

"Agama" berasal dari bahasan Sansakerta, "gam" artinya pergi; kemudian setelah mendapatkan awalan dan akhiran " $a$ " menjadi "agama", artinya menjadi jalan. Gam dalam bahasa Sansakerta ini mempunyai pengertian yang sama dengan to go (Inggris), gehen (Jerman), dan gaan (Belanda) yang artinya juga "pergi". Menurut Bahrun Rangkuti, agama berasal dari kata "a-gama”. Arti " $a$ " panjang ialah cara atau the way; sedangkan "gama" berasal dari kata Indojerman "gam" berarti sama dengan kata Inggris to go, yaitu berjalan atau pergi. Jadi agama artinya adalah cara-cara berjalan atau cara-cara untuk sampai pada keridlaan Tuhan. Dengan demikian, agama dirumuskan sebagai suatu jalan yang harus diikuti agar orang sampai ke suatu tujuan yang suci dan mulia (Kurnia, 2015).

Pendapat lain mengatakan juga bahwa agama berasal dari bahasa Sansakerta, yakni " $a$ " yang artinya tidak, dan "gam" artinya pergi, berubah, atau bergerak. Oleh karena itu dapat diartikan bahwa agama (maksudnya ajarannya) merupakan sesuatu yang tidak berubah, atau sesuatu yang kekal abadi.

Masih berkaitan dengan pengertian agama, ada juga pendapat bahwa agama berasal dari kata " $a$ " artinya tidak, dan "gama" artinya kacau. Jadi agama artinya sesuatu yang tidak kacau. Berdasarkan beberapa pendapat di atas, dapat disimpulkan bahwa agama adalah:

a. Jalan yang harus diikuti supaya orang sampai ke tujuan

b. Cara-cara berjalan atau cara-cara agar sampai ke suatu tujuan yang diridlai Tuhan 
26 Implementasi Nilai-nilai Moral dan Agama pada Anak Usia Dini

c. Sesuatu yang membuat tidak kacau (suatu tuntunan yang tidak membuat kacau manusia atau sesuatu yang menertibkan hidup)

\section{Unsur-unsur Pokok Agama}

Agama mengandung tiga unsur pokok yang harus ada di dalamnya. Ketiga unsur pokok itu menurut Endang Saifudin Ansari (Kurnia, 2015) adalah sebagai berikut:

a. Suatu sistem CREDO (tata keimanan atau tata keyakinan) atas sesuatu yang mutlak di luar diri manusia.

b. Suatu sistem RITUS (tata peribadatan) manusia kepada yang dianggapnya mutlak.

c. Suatu sistem NORMA (tata kaidah) yang mengatur hubungan manusia dengan alam lainnya sesuai dan sejalan dengan tata keimanan dan tata peribadatan termaksud di atas.

d. Unsur agama yang terakhir adalah sistem moral. Sistem moral biasa disebut sebagai "akhlaq". Akhlaq tidak dapat dipisahkan dari ibadah maupun keimanan sebab akhlaq pun merupakan manifestasi atau perwujudan iman terhadap Tuhan.

Tiga unsur pokok di atas harus ada pada agama sebagai syarat suatu agama. Dengan demikian secara garis besar, agama meliputi keimanan/keyakinan, peribadatan kepada sesuatu yang diyakini, dan tata kaidah hubungan manusia dengan alam semesta sesuai dengan tata keimanan dan tata peribadatan.

Dari unsur-unsur agama tersebut secara garis besar terdapat dua ajaran dasar, yaitu ajaran tentang apa yang harus diyakini dan ajaran tentang apa yang harus dikerjakan.

Ajaran tentang apa yang harus diyakini dinamakan pokok ajaran atau kepercayaan. Sedangkan ajaran tentang apa yang harus dikerjakan dinamakan cabang ajaran atau hukum perbuatan. Di dalam Agama islam, ajaran tentang keyakinan tersebut dinamakan "Iman" dan ajaran tentang apa yang harus dikerjakan dinamakan "Islam".

\section{Tujuan Pengembangan Nilai-nilai Agama Kepada Anak-anak}

Secara umum tujuan pengembangan nilai agama pada diri anak adalah meletakkan dasar-dasar keimanan dengan pola takwa kepada-Nya dan keindahan akhlak, cakap, percaya pada diri sendiri, serta memiliki kesiapan untuk hidup di tengah-tengah dan bersama-sama dengan masyarakat untuk menempuh kehidupan yang diridhai-Nya.

Adapun tujuan khusus pengembangan nilai agama pada anak-anak usia prasekolah yaitu:

a. Mengembangkan rasa iman dan cinta terhadap Tuhan

b. Membiasakan anak-anak agar melakukan ibadah kepada Tuhan

c. Membiasakan agar perilaku dan sikap anak didasari dengan nilai-nilai agama

d. Membantu anak agar tumbuh dan berkembang menjadi pribadi yang beriman dan bertakwa terhadap Tuhan

\section{Pertumbuhan dan Perkembangan Rasa Keagamaan Pada Anak-anak}

Bagaimana rasa keagamaan tumbuh pada diri anak-anak? Kemampuan berpikir konkrit dan berfantasi yang dimiliki anakanak merupakan tahap awal untuk sampai pada kemampuan berpikir abstrak. Berpikir abstrak adalah berpikir tentang hal-hal yang berada di luar wilayah jangkauan panca indera. Jika seorang anak sudah mampu berfantasi, berarti ia sudah akan mulai bisa menapak untuk memasuki dunia lain yang bersifat abstrak, termasuk hidup beragama.

Kemampuan dan kesenangan anak dalam berfantasi bisa melahirkan ide-ide baru di luar cara berpikir konkritnya. Misalnya anak-anak perempuan melahirkan ide untuk berperan sebagai ibu pada saat bermain boneka-bonekaan, dan anak laki-laki (ingin/suka) berperan sebagai bapak/ayahnya. Mereka bermain rumah-rumahan dan memerankan diri sebagai seorang ibu dan ayah di dalam sebuah keluarga

Dengan peran-peran hasil fantasi yang dimainkannya mereka meniru dan 
memindahkan segala atau sebagian bentuk ucapan, sikap, tindakan, atau perbuatan orang-orang dewasa ke dalam dirinya. Pada saat itu mereka sudah bisa memilih dan membedakan perannya masing-masing dalam permainan. Pada saat itu pula mereka mampu memerankan dirinya seperti orang-orang dewasa. Mereka mampu membedakan perbuatan yang baik dan yang buruk, yang boleh dilakukan dan yang tidak boleh, dan sebagainya.

Peran ayah dan ibu yang dimainkan anak-anak tidak muncul dengan sendirinya, melainkan dari hasil pengalaman dan pengamatan anak dalam kehidupan sehari-hari di rumahnya. Sedangkan pemilihan dan pengambilan peran yang dimainkannya itu merupakan perwujudan dari rasa kagum, salut, senang, bangga, dan cinta terhadap orang tuanya dalam memperlakukan (khususnya) dirinya dengna baik, penuh perhatian, dan kasih saying, sehingga mereka meniru peranperan tersebut.

Akumulasi dari rasa kagum, salut, senang, bangga, dan cinta anak-anak melahirkan tanggapan baru terhadap orang tuanya, terutama terhadap ayahnya. Ayah merupakan lambang kewibawaan dan ibu sebagai lambang kasih saying. Mereka dipandang oleh anak-anak sebagai sosok yang sempurna dan tanpa cela.

Siapakah orang yang pertama menanamkan benih dan menumbuhkan rasa keagamaan pada anak-anak? Orang tua di rumah merupakan faktor utama dan pertama dalam menentukan kepribadian anak termasuk agamanya. Agama seorang anak pada umumnya ditentukan oleh pendidikan, pengalaman, dan latihanlatihan yang dilaluinya sejak kecil terutama oleh orang tuanya di dalam keluarga. Dalam hal ini orang tua dapat menanamkan, menumbuhkan, dan mengembangkan dasar-dasar keimanan (keagamaan) pada diri anak-anaknya.

Jika orang tua mengerti agama, taat menjalankan perintah agama, mampu memberikan contoh yang baik (uswatun hasanah) dan mengarahkan anak-anaknya untuk hidup beragama dan memiliki akhlak yang mulia, tentu akan melaahirkan anak-anak yang memiliki dasar-dasar keimanan dan ketaatan yang kuat terhadap Tuhan. Sebaliknya jika orang tua acuh tak acuh dan sama sekali tidak taat menjalankan perintah agama; maka tidak ada perilaku keagamaan yang bisa diteladani dan ditiru oleh anak-anaknya.

Oleh karena itu keteladanan dan hubungan antara orang tua dengan anakanak di dalam keluarga mempunyai pengaruh yang sangat besar terhadap pertumbuhan dan perkembangan agama anak-anaknya. Jika orang tua menginginkan anak yang shaleh (taat beragama) maka mulailah dari diri sendiri. Orang tua harus memiliki kesiapan untuk membentuk dan mewujudkan keluarga yang taat menjalankan agama, tangguh dan berkualitas.

Kapan perasaan keagamaan mulai tumbuh pada diri anak-anak? Pertumbuhan agama tidak muncul dengan sendirinya, melainkan karena adanya rangsangan (stimulus) yang sangat kuat dan berulangulang yang muncul dari luar diri anakanak. Pertama, pendengaran anak-anak terangsang dengan suara/bahasa yang memuat nilai agama yang diucapkan berulang-ulang; kedua, pengelihatan (mata), anak-anak terangsang dengan sikap dan perilaku keagamaan yang berulangulang; dan ketiga, adanya pemicu bagi anak berupa fasilitas yang tersedia untuk meniru dan melakukan praktek keagamaan, sehingga proses peniruan (imitasi) terhadap perilaku keagamaan yang dilakukan oleh orangtuanya berlangsung dengan mulus dan tanpa hambatan.

Dengan demikian pertumbuhan agama pada anak-anak telah mucul sejak pendengaran (dan pengelihatan) mereka mulai berfungsi. Meskipun demikian pertumbuhan agama pada anak-anak tidak akan segera muncul atau tumbuh jika stimulus yang memuat pesan nilai-nilai keagamaan tidak atau kurang menarik perhatian anak-anak.

Menurut Darajat (Kurnia, 2015), pertumbuhan agama telah muncul ketika anak belum bisa bicara. Sebelum anak belum bisa bicara anak telah dapat melihat 
dan mendengarkan kata-kata yang sering diucapkan orang tuanya yang semula tidak mendapatkan perhatian dari anak-anak dan tidak mempunyai arti apa-apa, jika sering diucapkan dan terdengar oleh mereka maka akan menjadi pusat perhatiannya. Demikian juga sikap, mimik, dan situasi, saat orang tua mengucapkannya lambat laun akan diamatinya, dan selanjutnya ditirunya. Pada saat demikian, si anak belum mengerti tentang agama dan belum tahu tentang Tuhan. Tetapi anak telah tumbuh untuk memasuki kehidupan beragama.

Selanjutnya pengetahuan anak tentang tuhan dan pengertian anak tentang agama akan sejalan dengan pertumbuhan dan perkembangan kecerdasan dan pengalamannya.

\section{Sifat-sifat Pemahaman Anak Taman Kanak-kanak pada Nilai-nilai Keagamaan}

Sifat-sifat pemahaman anak usia Taman Kanak-kanak terhadap nilai-nilai keagamaan pada saat mengikuti kegiatan belajar mengajar di antaranya:

a. Unreflective: pemahaman dan kemampuan anak dalam mempelajari nilai-nilai agama sering menampilkan suatu hal yang tidak serius. Mereka melakukan kegiatan ibadah pun dengan sikap dan sifat dasar yang kekanak-kanakan. Tidak mampu memahami konsep agama dengan mendalam.

b. Egocentris: dalam mempelajari nilainilai agama, anak usia Taman Kanakkanak terkadang belum mampu bersikap dan bertindak konsisten. Anak lebih terfokus pada hal-hal yang menguntungkan dirinya.

c. Misunderstand: anak akan mengalami salah pengertian dalam memahami suatu ajaran agama yang banyak bersifat abstrak.

d. Verbalis dan Ritualis: kondisi ini dapat dimanfaatkan untuk mengembangkan nilai-nilai agama pada diri mereka dengan cara memperkenalkan istilah, bacaan, dan ungkapan yang bersifat agamis.
Seperti memberi latihan menghafal, mengucapkan, memperagakan, dan sebagainya

e. Imitative: anak banyak belajar dari apa yang mereka lihat secara langsung. Mereka banyak meniru dari apa yang pernah dilihatnya sebagai sebuah pengalaman belajar.

Dengan demikian guru dan orang tua harus memperhatikan sifat-sifat tersebut untuk kepentingan menentukan pendekatan pembelajaran yang tepat buat anak. Kita harus tetap melakukan pendekatan progresif dan penyadaran jiwa dan kepribadian mereka.

\section{Esensi, Prinsip-prinsip dan Bentuk Kegiatan Pengembangan nilai Keagamaan di PAUD}

\section{a. Esensi Pengembangan Nilai Keagamaan}

Pengembangan nilai keagamaan terhadap anak Usia Dini adalah suatu upaya pengembangan nilai-nilai keagamaan yang ditujukan kepada anak sejak lahir sampai dengan usia enam tahun yang dilakukan melalui pemberian rangsangan pendidikan untuk membantu pertumbuhan dan perkembangan jasmani dan rohani agar anak memiliki kesiapan dalam memasuki pendidikan lebih lanjut. Dalam Peraturan Pemerintah No. 27/1990 Pasal 1 tentang Pendidikan Prasekolah, dinyatakan:

Eksistensi Taman Kanak-kanak sangat strategis untuk membantu pertumbuhan dan perkembangan jasmani dan rohani terutama jiwa keagamaan anak di luar lingkungan keluarga sebelum memasuki pendidikan dasar yang diselenggarakan di jalur pendidikan prasekolah atau di jalur pendidikan luar sekolah.

Keberadaan Pendidikan Anak Usia Dini sangat strategis guna meletakkan dasar-dasar keagamaan. Menumbuhkembangkannya, dan menjadi motivasi spiritual sehingga menjadi pondasi yang kokoh dan sangat penting baik untuk melanjutkan pada jenjang 
pendidikan sekolah Dasar maupun sebagai modal awal yang baik guna menghadapi kehidupan yang akan datang.

\section{b. Prinsip-prinsip Kegiatan Pengembangan nilai Keagamaan di PAUD}

Dalam melaksanakan program pembentukan perilaku melalui pembiasaan, hendaknya memperhatikan prinsip-prinsip sebagai berikut :

1) Guru menciptakan hubungan yang baik dan akrab sehingga tidak ada kesan bahwa guru adalah figur yang menakutkan bagi anak.

2) Guru senantiasa bersikap dan bertingkah laku yang dapat dijadikan contoh/teladan bagi anak

3) Memberikan kesempatan kepada anak untuk membedakan dan memilih mana perilaku yang baik dan mana yang tidak baik. Guru sebagai pembimbing hanya mengarahkan dan menjelaskan akibat-akibatnya.

4) Dalam memberikan tugas kepada anak agar diusahakan berupa ajakan dan perintah dengan bahasa yang baik

5) Agar anak mau berperilaku sesuai dengan yang diharapkan guru memberikan rangsangan (motivasi) dan bukan paksaan.

6) Apabila ada anak yang berperilaku berlebihan, hendaknya guru berusaha untuk mengendalikan tanpa emosi.

7) Terhadap anak yang menunjukkan perilaku bermasalah, peran guru adalah sebagai pembimbing dan bukan penghukum.

8) Pelaksanaan program pembentukan perilaku bersifat luwes/fleksibel.

\section{c. Bentuk Kegiatan Pengembangan Nilai Moral di PAUD}

Untuk mencapai keberhasilan pembentukan kepribadian anak agar mampu terwarnai dengan nilai-nilai agama, maka perlu didukung oleh unsur keteladanan dari orang tua dan guru. Untuk tujuan tersebut dalam pelaksanaannya guru dapat mengembangkan strategi pembelajaran dalam bentuk kegiatan terprogram, kegiatan rutin, kegiatan spontan, dan keteladanan.

1) Kegiatan pengembangan nilai agama secara terprogram dilaksanakan dengan perencanaan khusus dalam kurun waktu tertentu untuk memenuhi kebutuhan anak secara individual, kelompok, dan atau klasikal di dalam maupun di luar kelas.

2) Kegiatan pengembangan agama secara tidak terprogram dapat dilaksanakan sebagai berikut:

a) Kegiatan Rutin, yaitu kegiatan yang dilakukan terjadwal, seperti: berdo'a, ibadah khusus keagamaan bersama, keberaturan, pemeliharaan kebersihan dan kesehatan diri.

b) Kegiatan Spontan, adalah kegiatan tidak terjadwal dalam kejadian khusus seperti: pembentukan perilaku memberi salam, membuang sampah pada tempatnya, antri, mengatasi pertengkaran, dan lain-lain.

c) Kegiatan Keteladanan, adalah kegiatan dalam bentuk perilaku sehari-hari seperti: berdo'a, berpakaian rapi, berbahasa yang baik, gemar menolong, memuji kebaikan dan atau keberhasilan orang lain, , sabar, dan lain-lain.

Selain itu Pengembangan nilai agama hendaknya dilaksanakan melalui kegiatan terintegrasi dan kegiatan khusus. Kegiatan terintegrasi berupa pengembangan materi nilai-nilai agama yang disisipkan melalui pengembangan bidang kemampuan dasar. Sedangkan kegiatan khusus merupakan program kegiatan yang pelaksanaannya tidak dimasukkan atau tidak harus dikaitkan dengan pengembangan bidang kemampuan dasar lainnya, sehingga membutuhkan waktu dan penanganan khusus.

7. Pokok-pokok

Materi Pengembangan Nilai Keagamaan pada Anak Usia Dini

Dalam proses pembinaan dan pengembangan nilai-nilai agama bagi anak 
usia Taman Kanak-kanak, muatan materi pembelajarannya harus bersifat:

a. Aplikatif: materi pembelajaran bersifat terapan, yang berkaitan dengan kegiatan rutin anak sehari-hari dan sangat dibutuhkan untuk kepentingan aktivitas anak, serta yang dapat dilakukan anak dalam kehidupannya.

b. Enjoyable: pengajaran materi dan materi yang dipilih diupayakan mampu membuat anak senang, menikmati dan mau mengikuti dengan antusias.

c. Mudah ditiru: materi yang disajikan dapat dipraktekkan sesuai dengan kemampuan fisik dan karakter lahiriah anak

Ada beberapa prinsip dasar dalam rangka menyampaikan materi pengembangan nilai-nilai agama bagi anak Taman Kanak-kanak di antaranya:

a. penekanan pada aktivitas anak seharihari

b. pentingnya keteladanan dari lingkungan dan orang tua/keluarga anak

c. kesesuaian dengan kurikulum spiral

d. prinsip developmentally appropriate practice (DAP)/ pembelajaran yang tepat sesuai dengan perkembangan anak

e. prinsip psikologi perkembangan anak

f. prinsip monitoring yang rutin

\section{Metode dan Pendekatan Pengembangan Nilai-nilai Keagamaan}

Pada prinsipnya pengembangan nilai keagamaan kepada anak adalah menanamkan dasar-dasar nilai agama dan mengembangkannya sehingga kelak menjadi adat kebiasaan. Untuk itu guru PAUD dituntut memiliki kemampuan professional dan komprehensif terutama dalam memilih dan menentukan metodemetode yang efektif dan efisien. Dengan demikian proses belajar mengajar berlangsung dengan singkat tanpa merebut hak anak untuk bermain; artinya bentuk kegiatan dilakukan dalam suasana terbuka dan menyenangkan.
Ada beberapa metode yang dapat digunakan untuk pengembangan nilai agama kepada anak-anak, diantaranya :

a. Metode bermain,

Bermain juga dapat digunakan sebagai alat pengembangan nilai agama; seperti bermain peran untuk mengabstraksikan perana Nabi Ibrahim As. Ketika mengajarkan kaummnya yang musrik untuk mencaribTuhan yang diawali dengan pengenalan benda-benda langit atau permainan pura-pura yang dapat mengembangkan nilai-nilai social, nilai moral, nilai sejarah, atau nilainilai agama, dan sebagainya.

b. Metode karyawisata

Dalam pendidikan Islam, karyawisata disebut Tadabur Alam. Metode karyawisata ini pun dapat dijadikan alat untuk mencapai semua program pengembangan di TK

c. Metode demonstrasi

Dalam pengembangannya nilai keagamaan, metode ini bisa dilakukan guru ketika menerangkan cara-cvara thaharah (berwudhu), cara-cara sholat, etika makan dan sebagainya.

d. Metode bercerita

Salah satu kegemaran anak-anak adalah mendengarkan cerita. Melalui cerita seorang guru dapat menerapkan nilai-nilai keagamaan kepada anak. Cerita yang dibawakan hendaknya yang berhubungan dengan dunia anakanak sehinga akan lebih menarik minat mereka untuk mendengarkan.

Dalam bercerita, guru hendaknya dapaty mendramatisasi berbagai cerita tentang kisah yang layak diteladani oleh anak. Bentuk cerita sebaiknya tidak didominasi fable, tetapi sebaiknya juga kisah-0kisah para Nabi dan rasul, beserta Mukjizatnya. Akan lebih baik lagi, apabila guru menerangkan cerita itu yang berhubungan dengan kehidupan para Nabi dan rasul Tuhan ketika masih kecil. Seperti bagaimana kehidupan Nabi Yusuf AS, Nabi Ibrahim, Nabi Muhammad SAW, dan sebagainya

e. Metode uswah hasanah 
Dalam Islam, metode Uswah Hasanah menempati porsi utama dan pertama, terutama untuk membentuk nilai dan perilaku yang baik bagi anak-anak. Pengemabangan nilai-nilai agama akan lebih tepat karena anak-anak memiliki kecenderungan untuk meniru perlaku yang diperankan atau yang ditampilkan guru.

\section{SIMPULAN}

Pengembangan nilai agama, moral dalam program pendidikan anak usia dini (AUD) dimasukkan dalam bidang pembentukan perilaku yang dilakukan secara terus menerus dan ada dalam kehidupan sehari-hari anak di PAUD. Tujuan pengembangan nilai-nilai/ pembentukan perilaku adalah mempersiapkan anak sedini mungkin mengembangkan sikap dan perilaku yang didasari oleh nilai agama dan moral sehingga dapat hidup sesuai dengan norma-norma yang dianut oleh masyarakat. Pembentukan perilaku ini berfungsi untuk mencapai beberapa hal: Menanamkan pembiasaan sikap dan perilaku yang didasari oleh nilai agama dan moral sehingga anak dapat hidup sesuai dengan nilai-nilai yang dijunjung oleh Masyarakat Membantu anak agar tumbuh menjadi pribadi yang matang dan mandiri Menanamkan budi pekerti yang baik Melatih anak untuk dapat membedakan sikap dan perilaku yang baik dan yang tidak baik sehingga dengan sadar berusaha menghindarkan diri dari perbuatan tercela Sebagai wahana untuk terciptanya situasi belajar anak yang berlangsung tertib, aktif, dan penuh perhatian Melatih anak didik untuk mencintai lingkungan yang bersih dan sehat Menanamkan kebiasaan disiplin dalam kehidupan sehari-hari

Pengembangan nilai moral dan agama dilakukan melalui proses knowing the good, reasoning the good, loving and feeling the good, and acting the good yaitu proses melibatkan aspek kognitif, emosi dan fisik dengan menanamkan nilai karakter kejujuran sehingga akhlak mulia bisa terukir menjadi habit of the mind, heart dan hands (Megawangi, 2010). Teknis pelaksanaan pengembangan nilai moral dan agama pada anak di TK secara formal dilakukan 15 - 20 menit setiap hari sebelum kegiatan belajar dimulai (apersepsi awal) dengan bentuk kegiatan dengan menggunakan metode: Melalui Ceramah (menerangkan konsep), Melalui permainan, Bercerita, Bernyanyi, keteladanan, Bermainperan, karyawisata, dan sebagainya. Adapun bentuk kegiatannya dilakukan melalui kegiatan rutin, spontan, keteladanan, dan terprogram. Cara pengembangan nilai agama pada anak meliputi mengenalkan tuhan, mengenalkan ibadah kepada-Nya, dan menanamkan akhlak yang baik.

\section{DAFTAR PUSTAKA}

Depdiknas. Kompetensi Guru (2007). Indonesia.

Dewey, J. (1997). Experience and Education. New York: Collier Books.

Fauziddin, M. (2016). Pembelajaran Agama Islam Melalui Bermain pada Anak Usia Dini (Studi Kasus di TKIT Nurul Islam Pare Kebupaten Kediri Jawa Timur). JURNAL PAUD TAMBUSAI, 2(2), 8-17.

Kementrian Pendidikan Nasional. (2012). Pedoman Pendidikan Karakter pada Pendidikan anak Usia Dini, Direktorat Pembinaan Pendidikan Anak Usia Dini Direktorat Jenderal Pendidikan Anak Usia Dini, Nonformal, dan Informal. Jakarta: Kemendiknas.

Kohlberg, L. (1995). Tahap - Tahap Perkembangan Moral (Alih bahasa John de Santo dan Agus Cremers SVD). Yogyakarta: Kanisius.

Kurnia, Y. (2015). Pengembangan Kemampuan Nilai-nilai Agama dan Moral di TK. Bandung: PPPPTK TK dan PLB.

Lickona, T. (1992). Educating for Character, How Our Schools Can Teach Respect and Responsibility. New York: Bantam Books.

Megawangi, R. (2010). Pengembangan Program Pendidikan Karakter di Sekolah; Pengalaman Sekolah Karakter. Jakarta.

Republik Indonesia. Sistem Pendidikan Nasional (2003). Indonesia. 